\title{
TRANSPORT INFRASTRUCTURE AND ECONOMIC GROWTH: PANEL DATA APPROACH FOR ARMENIA, GEORGIA AND TURKEY
}

\author{
Gohar BADALYAN ${ }^{1 *}$, Thomas HERZFELD ${ }^{2}$, Miroslava RAJCANIOVA ${ }^{1}$
}

\author{
Address: \\ ${ }^{1}$ Slovak Agricultural University in Nitra \\ ${ }^{2}$ Leibniz Institute of Agricultural Development in Transition Economies * \\ Corresponding author: Gohar Badalyan, e-mail: badalyangohar10@gmail.com
}

\begin{abstract}
Provision of efficient, reliable, and affordable infrastructure is essential for economic growth. Transportation infrastructure in particular, is vital to the prosperity of regions. To investigate the relationship and the direction of causality between transport infrastructure, investment in infrastructure and economic growth, we use panel cointegration analysis and panel causality analysis for three countries Armenia, Turkey, and Georgia. We use annual data of Armenia, Turkey and Georgia for the period 1982-2010.The tests proved the existence of more than one cointegrating vector indicating that the system under examination is stationary in more than one direction. The VECM results showed that gross capital formation and road/rail goods transported have a positive and statistically significant impact on economic growth in the short- run. Overall, the existence of bidirectional causality between economic growth and infrastructure investment, and between road and rail passengers carried and infrastructure investment was indicated in both the short and long-run.
\end{abstract}

Keywords: economic growth, transport infrastructure, panel cointegration, VECM JEL: H54, O18

\section{INTRODUCTION}

Provision of efficient, reliable, and affordable infrastructure is essential for economic growth. Transportation infrastructure in particular, is vital to the prosperity of regions. First, it links residents with employment, public services, shopping or social networks, and businesses to labour, consumers, and suppliers (Kirkpatrick, 2004). Second transport infrastructure may increase productivity of existing inputs and/or decrease transport and production costs making the region more attractive for investors (Pradhan and Bagchi, 2013). Besides this, transport infrastructure affects economic growth through the aggregated demand. The importance of transport infrastructure to economic growth has been recognized long ago in many studies (Wang, 2002; Esfahani \& Ramirez, 2003; Phang, 2003; Short \& Kopp, 2005; Pradhan, Bagchi, 2013). However, the causal link between infrastructure and growth may exist in the opposite direction, as countries with high levels of output will be able to fund higher infrastructure investments (Egert et al., 2009).

Using a panel data approach, we test the link between transport infrastructure, investment in infrastructure and economic growth in Armenia, Turkey, and Georgia over the period 1982 - 2010. The degree of relationship between transport infrastructure and economic growth relation is vital for transport infrastructure strategy and policies in these neighbour developing countries. There is bunch of literature sources dealing with the link between infrastructure and economic growth in different developed and developing countries. However, we are not aware of any of such study for Armenia, Georgia and Turkey. The purpose of choosing these countries is also that they are neighbour countries, with similar historical background. Two of these countries were the members of the former Soviet Union. Before independence of Georgia and Armenia from Soviet Union and the war between Azerbaijan and Armenia, the borders connecting the letter two countries were open.

The objective of this paper is to investigate the relationship and causality between economic growth, transport infrastructure, and investment in infrastructure. To achieve this aim, we use panel data approach to test for panel unit roots to identify the order of integration of the variables and heterogeneous panel cointegration technique to investigate the existence of a cointegration relationship between transport infrastructure, investment in it, and economic growth. Second, this study applies the Dynamic Ordinary Least Squares (DOLS) method and panel fully modified ordinary least square (FMOLS) to estimate the long-run relationship between the variables. The DOLS estimator allows correcting standard OLS for bias induced by endogeneity and serial correlation. The DOLS estimation method, however, allows us to confirm the general trend and direction of the causality obtained by the FMOLS method.

The contribution of our paper refers to the distinction between long-run and short-run causality. If we focus only on the long-run relationship panel 
cointegration estimation, it could cause misleading conclusions. To solve this problem, we make use of panel VECM in order to analyse both short- and long-run causality and check for the robustness of our empirical results.

The structure of the paper is the following: the recent development of transport infrastructure in Armenia, Turkey, and Georgia. Then the link between infrastructure and economic growth. In next section, we describe the data and methodology. In empirical results there are presented the results. Finally, the last section gives the conclusions.

\section{TRANSPORT INFRASTRUCTURE DEVELOPMENT IN ARMENIA, TURKEY, AND GEORGIA}

As it is mentioned above, three neighbour developing countries have been chosen in this study. Table 1 presents a comparison of transport infrastructure indicators between Armenia, Georgia and Turkey. Good transportation infrastructure and services are important preconditions for increasing trade, and achieving economic development.

Table 1. Comparison of transport infrastructure indicators between Armenia, Georgia and Turkey (2010, in $\mathrm{km}$ )

\begin{tabular}{llll}
\hline & Armenia & Georgia & Turkey \\
\hline Railways & & & \\
Total $(\mathrm{km})$ & 826 & 1566 & 9594 \\
Metro lines (km) & 12 & 27 & 118 \\
Roadways & & & \\
Total(km) & 7705 & 19103 & 367263 \\
Paved(km) & 7211 & 17975 & 328333 \\
Unpaved(km) & 494 & 1128 & 38930 \\
Motorways(km) & NA & NA & 2080 \\
State road(km) & 1686 & 2495 & 31395 \\
Provincial road(km) & 1747 & 6446 & 31390 \\
Other(km) & 4272 & 8541 & 302398 \\
Road density(km) & 25 & 29 & 54 \\
Motor vehicles & 103 & 155 & 155 \\
(per 1,000 people) & & 16 & 69 \\
Airports (number) & 5 & &
\end{tabular}

Source: UNECE, 2013, WDI, 2012

\section{Transport infrastructure development in Turkey}

After 1950, a transport policy, which focused mostly on road transportation, was adopted and average length of newly constructed railway lines decreased to $16 \mathrm{~km}$ per year. But since 2003 investments in all modes of transport have been increased and the government of Turkey has given special attention and priority to railways among other transport modes, which has resulted in allocation of large amount of investment and new rail transport policy. Approximately 10 billion US Dollars investment was allocated to railway infrastructure between 2002 and 2010. (Transportation in Turkey, Country Report, 2011). Turkey has a stateowned railway system under the responsibility of Ministry of Transport and Communications, which carries out supervision of Turkish State Railways (OECD/ITF 2009).

\section{Transport infrastructure development in Georgia}

Georgia's location makes it an important commercial transit route, and the country inherited a well-developed transportation system when it became independent in 1991. However, lack of money and political disorder allowed it to deprave somewhat since independence. Fighting in and around the Abkhazian Autonomous Republic in the northwest has isolated and cut some of the principal rail and highway links between Georgia and Russia.

Since the nineteenth century, Tbilisi has been the centre of the Caucasus region's highway system, a position reinforced during the Soviet era. The country's four principal highways radiate from Tbilisi roughly in the four cardinal directions, which include paved connection with Turkey. The government built the first rail links in the region from Baku on the Caspian Sea through Tbilisi in 1883; this route remains the principal rail route of Transcaucasia. Along the Black Sea, a rail route extends from the main east-west line into Russia, and two lines run south from Tbilisi--one to Armenia and the other to Azerbaijan. Service on the Tbilisi-to-Erevan line has been disrupted because the tracks pass through the area of armed conflict between Armenia and Azerbaijan. Tbilisi was one of the first cities of the Soviet Union to have a subway system. From 2007 to 2011 there invested 1.2 billion US dollars in transport infrastructure in Georgia (OECD, 2013).

Sources for infrastructure development are the: Ministry of Finance of Georgia, World Bank, Japan Bank for International Cooperation, Japan International Cooperation Agency, Asian Development Bank and European Bank for Reconstruction and Development.

In 2009, ADB approved the Road Corridor Investment Program, a \$500 million to finance strategic interventions in Georgia's road corridor aimed at traffic decongestion, road safety, and the promotion of regional trade flows. In 2010, ADB approved a \$300 million for the Sustainable Urban Transport Investment Program to improve the efficiency, reliability, and affordability of urban transport infrastructure and services (CRIFG, 2011).

\section{Transport infrastructure development in Armenia}

All developing countries, especially being a landlocked as Armenia have the problem of implementing transit carriages, infrastructure development, modernization of available transport stock, depends on transport and cross-border access. Only two international borders are open: those with Georgia to the north and Iran to the south. The eastern border with Azerbaijan was closed in 1991, and the western border with Turkey in 1993. This results in high transport costs, particularly for traded goods, and expensive infrastructure development and maintenance.

Armenia has a few railway lines and an extensive road network. The infrastructure has deteriorated rapidly due to lack of funds. In recent years, priority has been 
given to rehabilitation and reconstruction of infrastructure, with about \$350 million from external sources such as the Asian Development Bank (ADB), the European Bank for Reconstruction and Development, the Lincy Foundation, etc.(Armenia's Transport Outlook, ADB, 2011).

The main development of Armenian road network took place during the years 1950-1980, which resulted in quite solid road network. Armenia's railway network includes the metro system that serves passengers in the capital. Armenian Railways was established in 1991 as a closed joint-stock company. Prior to independence, it was part of the Trans-Caucasus Railway, headquartered in Tbilisi, Georgia, which also included the Azerbaijani and Georgian networks. Most of Armenia Railways was built during the Soviet era. Some of the infrastructure was damaged during the 1988-1994 conflict with Azerbaijan (Country Infrastructure Report, RA, 2011).

\section{The link between transport infrastructure and economic growth}

There have been numerous studies on the transport infrastructure and economic development related issues in the past decades. All the studies detect an effect of investments in infrastructure and economic growth. However, the views differ with respect to the size of this effect. The first studies dealing with this topic, revealed that transport acts as a necessary condition for the growth to occur. Aschauer (1989) was one of the first estimating the macro effect of infrastructure investment on American economy. He found a strong impact of infrastructure capital on aggregate TFP. Many researchers, e.g. Munnell (1990), Ford and Poret (1991) and others followed his work. The results of these first studies suggested high returns of infrastructure investment. However these studies were later on criticized by other authors for unrealistic results (Gramlich 1994). Contrary to high estimates in these first studies, later results were predicting impacts that are more moderate. They explained that a first shock in infrastructure could cause great effect, but after the basic infrastructure was constructed, new investment would not cause much effect (Huang \& Harata, 2010). According to Banister and Berechman (2001), it is widely agreed that the economic growth happens mainly due to capital, labor, etc. and only partly relying on the infrastructure improvement.

Canning and Pedroni (1999) used Granger causality test between investments in three types of economic infrastructure i.e., kilometers of paved road, kilowatts of electricity generating capacity, and number of telephones based on data from a panel of 67 countries for the period 1960-1990. They found strong evidence of causality running in both directions between each of the three infrastructure variables and GDP among a significant number of the countries investigated. Demurger (2001) used panel data from a sample of 24 Chinese provinces throughout the 1985 to 1998 period. She estimated a growth model and found out that transport facilities are a key differentiating factor in explaining the growth gaps.

Esfahani and Ramirez (2003) developed a structural model of infrastructure and growth for 75 countries. They found that the impact of infrastructure on GDP growth turns out to be substantial, but depends on institutional and economic characteristics.

Canning (2004) used panel cointegration technique and found that in general both short run and long run causality is bi-directional, with infrastructure responding to GDP per capita but GDP per capita also responding to infrastructure shocks. Herranz-Loncan (2007) analysed the impact of infrastructure investment on Spanish economic growth using VAR system. His paper showed that investment in local scope infrastructure exerted a clearly positive impact on Spanish economic growth between 1850 and 1935. Pradhan and Bagchi (2013) used Vector Error Correction Model to examine the effect of transport (road and rail) infrastructure on economic growth in India over the period 1970-2010. They found that transport infrastructure not only influences economic growth but also gross capital formation. Kumo (2012) conducted pairwise Granger causality tests between economic growth, economic infrastructure investment, and employment in South Africa for the period 1960-2009 using bivariate vector autoregression (VAR) model with and without a structural break. His results indicate a strong causality between economic infrastructure investment and GDP growth that runs in both directions.

\section{DATA AND METHODOLOGY}

\section{Data}

We use annual data of three neighbouring developing countries for the period 1982-2010.The lack of data may have introduced some biases in the final figures, and that is way we took it into consideration while interpretation the results. All the data are obtained from the World Bank, World Development Indicators (WDI, 2012).

To analyse the nexus between transport infrastructures, investments in infrastructure and economic growth, the equation (1) is estimated.

$$
Y_{i, t}=\beta_{0+} \beta_{1} G C F_{i, t}+\beta_{2} R R G T_{i, t}+\beta_{3} R R P C_{i, t}+\beta_{4} R R N L_{i, t}+u_{i t}
$$

The annual data on gross domestic product (GDP) in constant 2005 US dollars are used as a proxy for economic growth (Y), road, and railway transport, which are: RRGT is roads and rail goods transported (million ton-km), RRPC is roads and rail passengers carried (million passenger-km), and RRNL is roads and rail network length $(\mathrm{km})$ as a proxy for transport infrastructure. Later on gross domestic capital formation (GCF) in constant 2005 US dollars is used as a proxy for infrastructure investment. All variables are transformed into natural logarithms. 


\section{Panel unit-root tests}

Panel unit root tests are used to examine the degree of integration between the variables. To assess the stationarity properties of the variables used. In this study we have used five different panel unit root tests including LLC test proposed by Levin, Lin and Chu (2002); IPS test proposed by Im, Pesaran and Shin (2003), Fishertype tests using ADF and PP tests of Maddala and Wu (1999) and Choi (2001), Breitung (2000) and Hadri (2000). The LLC test assumes that there is a common unit root process across the cross-sections. This test has null hypothesis of unit root, whereas the alternative hypothesis does not have a unit root. The IPS, Fisher$\mathrm{ADF}$, and Fisher-PP tests assume that there are individual unit root processes across the cross-sections. These three tests have null hypothesis of unit root, whereas the alternative hypothesis of some cross sections do not contain a unit root.

Breitung (2000) indicates that if individual specific trends are included the LLC and IPS tests are losing power. This is due to the bias correction that also removes the mean under the sequence of local alternative. He suggests a test that does not employ a bias adjustment and with significantly higher power than that of LLC or the IPS tests. The null hypothesis of Breitung's test is that the panel series exhibit non-stationary difference and the alternative hypothesis is that the panel series are stationary.

The Hadri-test (2000) is a residual-based Lagrange Multiplier (LM) test where the null hypothesis is that there is no unit root in any of the series in the panel against the alternative of a unit root in the panel.

\section{Panel cointegration analysis}

Cointegration implies the existence of a long-run relationship between variables. The principle of testing for cointegration is to test whether two or more integrated variables deviate significantly from a certain relationship (Abadir \& Taylor, 1999). In other words, if the variables are cointegrated, they move together over time so that short-term disturbances will be corrected in the long-term. If the series contain a panel unit root, then we use panel cointegration test technique. Here we apply the most popular panel cointegration test developed by Pedroni (1999, 2004) to determine whether a relationship exists between economic growth, investment in infrastructure and transport infrastructure.

Pedroni (1999, 2004) proposed two types of cointegration tests: panel tests and group tests. The first group of tests is termed "within dimension". It includes the panel-v, panel rho(r), panel non-parametric (PP) and panel parametric (ADF) statistics. Second, the group tests based on the between dimension method (i.e. group mean panel cointegration statistics test) which includes three statistics: group rho-statistic, group PP-statistic, and group ADF-statistic. These seven statistics are asymptotically distributed as standard normal and the detailed description of panel cointegration test statistics can be found in Pedroni (1999, 2004).

The seven of Pedroni's tests are based on the estimated residuals from the following long run model: $y_{i t}=\alpha_{i}+\sum_{j=1}^{m} \beta_{j i} x_{j i t}+\varepsilon_{i t}$

where $\mathrm{i}=1 ; \ldots ; \mathrm{N}$ for each country in the panel and $\mathrm{t}=1$, .., T refers to the time period. The parameter $\alpha_{i}$ allows for the possibility of country-specific fixed effects. The estimated residuals, denoted by $\varepsilon_{\mathrm{it}}$; represent deviations from the long-run relationship. The null hypothesis of no cointegration, $\rho_{i}=1$, is tested by conducting a unit root test on the residuals as follows:

$\varepsilon_{i t}=\rho_{i} \varepsilon_{i(t-1)}+w_{i t}$

In our empirical analysis, we used three cointegration test methods. The first set of tests is Pedroni (2004). The second set of test is Kao (1999), which is based on the Engle-Granger two-step procedure, and imposes homogeneity on the members in the panel and is a generalization of the Dickey-Fuller (DF) and Augmented Dickey-Fuller (ADF) tests in the context of panel data. Finally, Fisher's test to aggregate the p-values of the individual Johansen maximum likelihood cointegration test statistics (Maddala andWu, 1999) was used. The Fisher test is a non-parametric test that does not assume homogeneity in the coefficients.

All the tests involve the null hypothesis of no cointegration and use the residuals derived from a panel regression to construct the test statistics and determine the distributions. After appropriate standardization, all the test statistics have an asymptotic distribution.

\section{Panel FMOLS and DOLS estimation}

Given that our variables are cointegrated, the next step is the estimation of the long-run relationship between economic growth, investment in infrastructure and transport infrastructure.

There are various estimators available for estimating a cointegration vector using panel data, including with-and between group such as OLS estimators, fully modified OLS (FMOLS) estimators, and dynamic OLS estimators (DOLS).

In the cointegrated panels, using the ordinary least squares (OLS) method to estimate the long-run equation leads to a biased estimator of the parameters unless the regressors are strictly exogenous, so that the OLS estimators cannot generally be used for valid inference.

Pedroni (2001) proposes fully modified ordinary least square (FMOLS) estimation while Kao and Chiang (2000) and Mark and Sul (2002) recommend the dynamic ordinary least squares (DOLS) as alternative methods of panel cointegration estimation.

FMOLS is a non-parametric approach and takes into account the possible correlation between the error term and the first differences of the regressors as well as the presence of a constant term, to dealing with corrections for serial correlation (Maeso-Fernandez et al., 2006). Both FMOLS and DOLS provide consistent estimates of standard errors that can be used for assumption. The panel DOLS estimation is fully parametric and offers a computationally convenient 
alternative to the panel FMOLS estimator proposed by Phillips and Moon (1999) and Pedroni (2004). One of the disadvantages of using the DOLS test is that degrees of freedom are lowered by leads and lags (MaesoFernandez et al., 2004, 2006).

For estimate FMOLS and DOLS let us consider the following fixed effect panel regression (Eq. 4).

$\mathrm{y}_{\mathrm{it}}=\alpha_{i}+\mathrm{x}_{i t} \beta+\mathrm{u}_{\mathrm{it}}, \mathrm{i}=1, \ldots, \mathrm{N}, \mathrm{t}=1, \ldots, \mathrm{T}$

where $y_{i t}$ is a matrix $(1,1), \beta$ is a vector of slopes $(k, 1)$ dimension, $\alpha_{i}$ is individual fixed effect, $u_{i t}$ are the stationary disturbance terms. It is assumed that $x_{i t}(k, 1)$ vector is integrated processes of order one for all $i$, where:

$\mathrm{x}_{\mathrm{it}}=\mathrm{x}_{i t-1}+\varepsilon_{\mathrm{it}}$

Under these specifications, Eq. (2) describes a system of cointegrated regressions, i.e. $y_{i t}$ is cointegrated with $x_{i t}$. By examining the limiting distribution of the FMOLS and DOLS estimators in co-integrated regressions Kao and Chiang (2000) show that they are asymptotically normal. The FMOLS estimator is constructed by making corrections for endogeneity and serial correlation to the OLS estimator and is defined by Eq. 6.

$\widehat{\beta}_{\mathrm{FM}}=\left[\sum_{\mathrm{i}=1}^{\mathrm{N}} \sum_{\mathrm{t}=1}^{\mathrm{T}}\left(\mathrm{x}_{i t}-\overline{x_{i}}\right)\right]^{-1}\left[\sum_{\mathrm{i}=1}^{\mathrm{N}}\left(\sum_{\mathrm{t}=1}^{\mathrm{T}}\left(\mathrm{x}_{i t}-\overline{x_{i}}\right) \widehat{\mathrm{y}_{1 \mathrm{t}}^{+}}+\right.\right.$ $\left.\left.\mathrm{T} \widehat{\Delta_{\varepsilon \mu}^{+}}\right)\right]$

where $\widehat{\Delta_{\varepsilon \mu}^{+}}$is the serial correlation correction term and $\widehat{y_{t t}^{+}}$ is the transformed variable of $y_{i t}$ in order to achieve the endogeneity correction. The serial correlation and the endogeneity can also be corrected by using DOLS estimator. In order to obtain an unbiased estimator of the long-run parameters, DOLS estimator uses parametric adjustment to the errors by including the past and the future values of the differenced I(1) regressors. The DOLS estimator is obtained from the Equation 7.

$\mathrm{Y}_{\mathrm{it}}=\alpha_{\mathrm{j}}+\beta \mathrm{ix}_{\mathrm{it}}+\sum_{k=q}^{q} \mathrm{c}_{\mathrm{ik}} \Delta \mathrm{x}_{\mathrm{it}+\mathrm{k}}+\mu_{\mathrm{it}} ; \quad \mathrm{t}=1$,

$\mathrm{T} \mathrm{i}=1, \ldots \mathrm{N}$

where $\alpha_{i}$ indicates the country-specific effect and $c_{i k}$ is the coefficient of a lead or lag of first differenced explanatory variables. Term $\mu_{i t}$ denotes the disturbance terms following the $\mathrm{I}(0)$ process. The estimated coefficient of DOLS is given by Eq. 8 .

$\widehat{\beta}_{\mathrm{DOLS}}=\sum_{\mathrm{i}=1}^{\mathrm{N}}\left(\sum_{\mathrm{t}=1}^{\mathrm{T}} \mathrm{z}_{\mathrm{it}} \mathrm{z}_{\mathrm{it}}^{\prime}\right)^{-1}\left(\sum_{\mathrm{t}=1}^{\mathrm{T}} \mathrm{z}_{\mathrm{it}} \widehat{\mathrm{y}_{1 \mathrm{t}}^{+}}\right)$

where $z_{i t}=\left[x_{i t}-\bar{x}_{l}, \Delta x_{i, t-q}, \ldots, \Delta x_{i, t+q}\right]$ is $2(q+1) * 1$ vector of regressors.
Causal effects between growth and infrastructure investments

To examine the causal relationship a panel vector error correction model is estimated (Pesaran et al., 1999). The Engle and Granger (Engle and Granger, 1987) two-step procedure is undertaken by first estimating the long-run model specified in Eq. (2) to obtain the estimated residuals. Next, defining the lagged residuals from Eq. (2) as the error correction term, the following dynamic error correction model is estimated (Eq. 9 -Eq.13).

$\Delta \mathrm{Y}_{\mathrm{it}}=\xi_{1 \mathrm{j}}+\sum_{k=1}^{q} \psi_{11 \mathrm{ik}} \Delta \mathrm{Y}_{\mathrm{it}-\mathrm{k}}+\sum_{k=1}^{q} \psi_{12 \mathrm{ik}} \Delta \mathrm{GCF}_{\mathrm{it}-\mathrm{k}}+$ $\sum_{k=1}^{q} \psi_{13 \mathrm{ik}} \Delta \mathrm{RRGT}_{\mathrm{it}-\mathrm{k}}+\sum_{k=1}^{q} \psi_{14 \mathrm{ik}} \Delta \mathrm{RRPC}_{\mathrm{it}-\mathrm{k}}+$

$\sum_{k=1}^{q} \psi_{15 \mathrm{ik}} \Delta \mathrm{RRNL}_{\mathrm{it}-\mathrm{k}}+\lambda_{1 \mathrm{i}} \varepsilon_{\mathrm{it}-1}+\mathrm{u}_{1 \mathrm{it}}$

$\Delta \mathrm{GCF}_{\text {it }}=$

$\xi_{2 \mathrm{j}}+\sum_{k=1}^{q} \psi_{21 \mathrm{ik}} \Delta \mathrm{Y}_{\mathrm{it}-\mathrm{k}}+\sum_{k=1}^{q} \psi_{22 \mathrm{ik}} \Delta \mathrm{GCF}_{\mathrm{it}-\mathrm{k}}+$

$\sum_{k=1}^{q} \psi_{23 \mathrm{ik}} \Delta \mathrm{RRGT}_{\mathrm{it}-\mathrm{k}}+\sum_{k=1}^{q} \psi_{24 \mathrm{ik}} \Delta \mathrm{RRPC}_{\mathrm{it}-\mathrm{k}}+$

$\sum_{k=1}^{q} \psi_{25 \mathrm{ik}} \Delta \mathrm{RRNL}_{\mathrm{it}-\mathrm{k}}+\lambda_{2 \mathrm{i}} \varepsilon_{\mathrm{it}-1}+\mathrm{u}_{2 \mathrm{it}}$

$\triangle \mathrm{RRGT}_{\mathrm{it}}=$

$\xi_{3 \mathrm{j}}+\sum_{k=1}^{q} \psi_{31 \mathrm{ik}} \Delta \mathrm{Y}_{\mathrm{it}-\mathrm{k}}+\sum_{k=1}^{q} \psi_{32 \mathrm{ik}} \Delta \mathrm{GCF}_{\mathrm{it}-\mathrm{k}}+$

$\sum_{k=1}^{q} \psi_{33 \mathrm{ik}} \Delta \mathrm{RRGT}_{\mathrm{it}-\mathrm{k}} \sum_{k=1}^{q} \Psi_{34 \mathrm{ik}} \Delta \mathrm{RRPC}_{\mathrm{it}-\mathrm{k}}+$

$\sum_{k=1}^{q} \psi_{35 \mathrm{ik}} \Delta \mathrm{RRNL}_{\mathrm{it}-\mathrm{k}}+\lambda_{3 \mathrm{i}} \varepsilon_{\mathrm{it}-1}+\mathrm{u}_{3 \mathrm{it}}$

$\triangle \mathrm{RRPC}_{\mathrm{it}}=$

$\xi_{4 \mathrm{j}}+\sum_{k=1}^{q} \psi_{41 \mathrm{ik}} \Delta \mathrm{Y}_{\mathrm{it}-\mathrm{k}}+\sum_{k=1}^{q} \psi_{42 \mathrm{ik}} \Delta \mathrm{GCF}_{\mathrm{it}-\mathrm{k}}+$

$\sum_{k=1}^{q} \psi_{43 \mathrm{ik}} \Delta \mathrm{RRGT}_{\mathrm{it}-\mathrm{k}}+\sum_{k=1}^{q} \psi_{44 \mathrm{ik}} \Delta \mathrm{RRPC}_{\mathrm{it}-\mathrm{k}}+$

$\sum_{k=1}^{q} \psi_{45 \mathrm{ik}} \Delta \mathrm{RRNL}_{\mathrm{it}-\mathrm{k}}+\lambda_{4 \mathrm{i}} \varepsilon_{\mathrm{it}-1}+\mathrm{u}_{4 \mathrm{it}}$

$\triangle \mathrm{RRNL}_{\mathrm{it}}=$

$\xi_{5 \mathrm{j}}+\sum_{k=1}^{q} \psi_{51 \mathrm{ik}} \Delta \mathrm{Y}_{\mathrm{it}-\mathrm{k}}+\sum_{k=1}^{q} \psi_{52 \mathrm{ik}} \Delta \mathrm{GCF}_{\mathrm{it}-\mathrm{k}}+$

$\sum_{k=1}^{q} \psi_{53 \mathrm{ik}} \Delta \mathrm{RRGT}_{\mathrm{it}-\mathrm{k}}+\sum_{k=1}^{q} \psi_{54 \mathrm{ik}} \Delta \mathrm{RRPC}_{\mathrm{it}-\mathrm{k}}+$

$\sum_{k=1}^{q} \psi_{55 \mathrm{ik}} \Delta \mathrm{RRNL}_{\mathrm{it}-\mathrm{k}}+\lambda_{5 \mathrm{i}} \varepsilon_{\mathrm{it}-1}+\mathrm{u}_{5 \mathrm{it}}$

where $\Delta$ is the first-difference, $\mathrm{k}$ is the lag length set at one based on likelihood ratio tests, and $\mathrm{u}$ is the serially uncorrelated error term. From (Eq. 9) to (Eq. 13), shortrun causality is determined by the statistical significance of the partial F-statistic associated with the corresponding right hand side variables. Long-run causality is revealed by the statistical significance of the respective error correction terms using a t-test. Short-run causality is determined by the statistical significance of the F-statistic. The presence (or absence) of long-run causality can be established by examining the significance using a t-statistic on the coefficient $\lambda$, of the error correction term, $\varepsilon_{\mathrm{it}-1}$ in Eq. 9- Eq. 13.

\section{EMPIRICAL RESULTS}

\section{Panel Unit Root Tests Results}

In Table 2 the results of the LLC, IPS, Fisher-ADF, and Fisher-PP, Breitung and Hadri panel unit root tests for each of the variable are presented. We have performed each test for the level and first difference of transport infrastructure variables, investment in infrastructure and economic growth variables. 
For the variables in level form, the null hypothesis of a unit root cannot be rejected for the IPS LLC, Fisher$\mathrm{ADF}$, and Fisher-PP tests, except for RRNL variable while the Hadri test rejects the null hypothesis at the $1 \%$ significance level for all variables. After taking the first difference of variables, the five tests reject the null hypothesis at the $1 \%$ significance level. So, we can conclude that all variables (in first differences) are nonstationary and integrated of order one or I(1).

The null hypothesis is that the variable follows a unit root process, except for the Hadri Z-stat and the Heteroscedastic Consistent Z-stat. Probabilities for the Fisher-type tests are computed using an asymptotic Chisquare distribution. All other tests assume asymptotic normality.

\section{Panel Cointegration Test Results}

For the robustness check, this paper used three kinds of panel cointegration tests, i.e. Pedroni's (2004), Kao's (1999), and Johansen's Fisher panel cointegration tests. Table 3 reports the within and between dimension results of the panel cointegration tests. As shown in Table 3, the results of Pedroni's (2004) heterogeneous panel tests indicate that the null of no cointegration can be rejected at the $1 \%$ and $10 \%$ significance levels except for the panel rho-statistic, the panel pp-statistic and the group rho-statistic and the group pp-statistic.

Table 4 reports the results of Kao's (1999) residual panel cointegration tests, which reject the null of no cointegration at the $1 \%$ significance level.

Finally, the results of Johansen's Fisher panel cointegration test are reported in Table 5. Fisher's test (trace test statistics or maximum eigenvalue test statistics) supports the presence of a cointegrated relationship among the five variables at the $1 \%$ and $5 \%$ levels.
Table 3 Pedroni residual cointegration test results (GDP as dependent variable)

\begin{tabular}{lrr}
\hline & Statistics & Probability \\
\hline & Within dimension & \\
Panel v-Statistic & $1.655^{* * *}$ & 0.001 \\
Panel rho-Statistic & 1.126 & 0.870 \\
Panel PP-Statistic & -1.155 & 0.123 \\
Panel ADF-Statistic & $-1.183^{*}$ & 0.101 \\
& 1.765 & \\
Group rho-Statistic & 0.482 & 0.961 \\
Group PP-Statistic & $-1.614^{*}$ & 0.685 \\
Group ADF-Statistic & 0.053 \\
\hline Source: Calculated & & \\
Notes: The test statistics asymptotically distributed as standard normal. \\
Automatic lag length selected according to the Schwarz Information \\
Criteria (SIC). \\
*** Indicate that the parameters are significant at the 1\% level. \\
* Indicate that the parameters are significant at the 10\% level
\end{tabular}

Table 4. Kao's residual cointegration test results (GDP as dependent variable)

\begin{tabular}{llr}
\hline & t-statistic & Probability \\
\hline ADF & $-2.911^{* * *}$ & 0.00 \\
\hline
\end{tabular}

Source: Calculated

Note: The ADF is the residual-based ADF statistic (Kao, 1999).

*** Indicates that the parameters are significant at the $1 \%$ level.

Table 5. Panel cointegration test results of a Fisher-type test using an underlying Johansen methodology.

\begin{tabular}{lrrrr} 
& \multicolumn{2}{l}{$\begin{array}{l}\text { Fisherstatistic } \\
\text { (from }\end{array}$} & \multicolumn{3}{l}{$\begin{array}{l}\text { Fisherstatistic } \\
\text { (from max-eigen } \\
\text { Model }\end{array}$} & tracetest) & Prob. & test) & Prob. \\
\hline None & $71.59 * * *$ & 0.000 & $48.29 * * *$ & 0.000 \\
At most 1 & $52.72^{* * *}$ & 0.000 & $51.70^{* * *}$ & 0.001 \\
At most 2 & $21.26^{* * *}$ & 0.002 & $16.81^{* *}$ & 0.010 \\
At most 3 & 8.93 & 0.178 & 9.39 & 0.230 \\
At most 4 & 5.81 & 0.445 & 5.81 & 0.445 \\
\hline
\end{tabular}

Source: Calculated

Notes: Asymptotic p-values are computed using a Chi-square distribution.

*** Indicates that the parameters are significant at the $1 \%$ level

** Indicates that the parameters are significant at the $5 \%$ level.

Table 2. Panel unit root test results

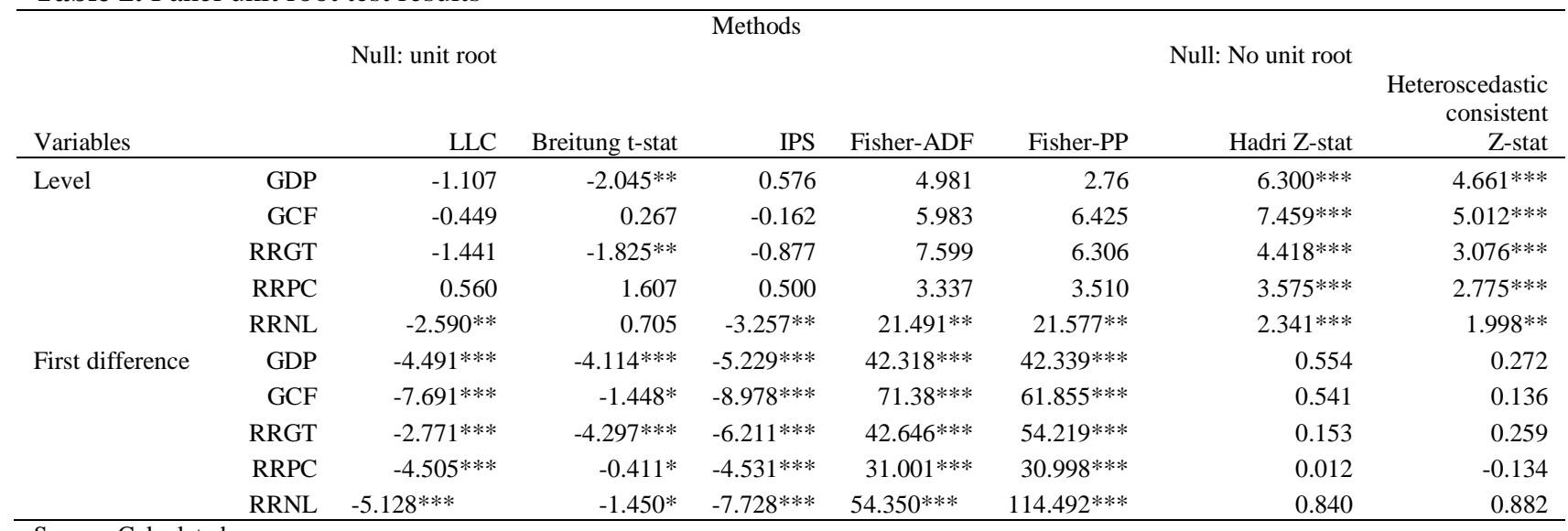

Source: Calculated

Notes: $\Delta$ denotes the first difference. The optimal lag length is selected automatically using the Schwarz information criteria.

$* * *$ Indicate that the parameters are significant at the $1 \%$ level. ** Indicate that the parameters are significant at the $5 \%$ level. * Indicate that the parameters are significant at the $10 \%$ level 
Thus, we conclude that there is a panel long-run equilibrium relationship among variables, meaning that variables of economic growth, investment in infrastructure and variables of transport infrastructure (rail and road passenger carried, rail and road goods transported and rail and roads network length) move together in the long run. Dickey et al. (1994) show that the existence of more than one cointegrating vector indicates that the system under examination is stationary in more than one direction.

\section{Panel estimation results}

FMOLS and DOLS test results are presented in Tables 6 . Results of panel FMOLS and DOLS indicate that transport infrastructure and investments in infrastructure are correlated with economic growth in Armenia, Georgia and Turkey.

Table 6. Panel FMOLS and Dynamic OLS long-run estimates (GDP as dependent variable)

\begin{tabular}{llll}
\hline \multicolumn{3}{l}{ FMOLS } & \multicolumn{3}{l}{} \\
\multicolumn{1}{l}{ Independent variables } & & \\
GCF & RRGT & RRPC & RRNL \\
0.30 & -0.02 & 0.08 & 0.03 \\
$\left(9.13^{* * *}\right)$ & $(-0.78)$ & $\left(4.24^{* * *}\right)$ & $\left(2.06^{* *}\right)$ \\
\hline DOLS & & & \\
\multicolumn{1}{l}{ Independent variables } & & RRNL \\
GCF & RRGT & RRPC & \\
0.38 & 0.05 & 0.07 & \\
$\left(5.63^{* * *}\right)$ & $\left(-2.23^{* *}\right)$ & $\left(2.79^{* * *}\right)$ & $0.02(0.74)$ \\
\hline
\end{tabular}

Source: Calculated

Note: t-statistics are in parentheses.

***Indicates that the estimated parameters are significant at $1 \%$ level.

$* *$ Indicates that the estimated parameters are significant at $5 \%$ level.

It is important to note again that the DOLS method has the drawback of reducing the number of degrees of freedom by including leads and lags in the variables studied, leading to less robust estimates. As our sample size is already small in both dimensions of time and the number of countries, the DOLS estimation may yield less robust results. The DOLS estimation method however, allows us to confirm the general trend and direction of the causality obtained by the FMOLS method. All of the estimated coefficients are positive and statistically significant at the $1 \%$ and $5 \%$ levels except RRGT and RRNL variables. Overall, the results of this study show that there is a strong long-run relationship between GDP, GCF RRPC, and RRNL in FMOLS and GDP, GCF, RRGT and RRPC in DOLS. The results indicate that a $1 \%$ increase in GCF is correlated with an increase in GDP by $0.30 \%$. Consequently, it is seen from the Table 6, that there is strong relationship of economic growth and investment in infrastructure.

\section{Panel causality results}

Taking into consideration the basis of cointegration results, VECM was used to estimate the direction of causality. The results of the VECM with five simultaneous equations for the analysis of the causal relationships between economic growth, gross capital formation (infrastructure investment) and transport infrastructure are presented in Table 7 . We report the results of the short-run and long-run Granger-causality tests for panel. The optimal lag structure of one year is chosen using the Akaike and the Schwarz Information Criterions.

The significance of causality tests are determined by the Wald F-test. According to Table 7 Eq. (5a) shows that gross capital formation, road and rail goods transported have a positive and statistically significant impact in the short- run on economic growth. On the other hand, the impact of road and rail passengers carried and road and rail network length variables are statistically insignificant in the short-run. This highlights the importance of infrastructure investment and RRGT variable in the economic growth process in selected countries. Furthermore, the error correction term is negative and statistically significant at $1 \%$ and denotes the speed of adjustment to long-run equilibrium.

From Eq. (5b), it appears that economic growth has positive and statistically significant impact in the short- run on gross capital formation, when road and rail passengers carried variable has negative impact. Rail and road goods transported and rail and road network length transport infrastructure variables have no impact. Then, there is complementarity between economic growth and gross capital formation and rail and road RRPC and gross capital formation. The error correction term is statistically significant at $1 \%$ and assumes that gross capital formation responds to deviations from long-run equilibrium.

With regard to Eq. (5c), the impact of variables is not significant, but there is evidence for long- run adjustment, because the error correction term is statistically significant at $10 \%$. With respect to Eq. (5d), GDP and RRNL have a positive and statistically significant impact on RRPC in the short-run, while the impact of gross capital formation and RRGT is negative. Finally, in Eq. (5e), GDP has a positive and significant impact on road and rail network length, whereas other three variables are statistically insignificant.

Regarding long-run dynamics, based on the statistical significance of the error correction terms from Eq. (5d) and (5e), RRPC is statistically significant at 5\% and denotes the speed of adjustment to long-run equilibrium, but RRNL responds to deviations from longrun equilibrium. Overall, the existence of bidirectional causality between economic growth and gross capital formation, and between road and rail passengers carried and gross capital formation was indicated in both the short and long-run. 
Table 7. Panel causality test results

\begin{tabular}{|c|c|c|c|c|c|c|c|c|}
\hline & \multicolumn{8}{|c|}{ Source of causation (independentvariable) } \\
\hline & \multicolumn{5}{|l|}{ Short run } & \multicolumn{3}{|c|}{ ong run } \\
\hline & $\Delta \mathrm{GDP}$ & $\Delta \mathrm{GCF}$ & $\Delta$ RRGT & $\triangle \mathrm{RRPC}$ & $\triangle \mathrm{RRNL}$ & ECT1 & ЕСТ2 & ЕСТ3 \\
\hline \multirow[t]{3}{*}{$\Delta \mathrm{GDP}$} & & $9.201^{* * *}$ & $2.733^{*}$ & 0.321 & 0.067 & 0.030 & $-0.53 * * *$ & -0.007 \\
\hline & & $(0.00)$ & $(0.10)$ & (057) & $(0.79)$ & $(0.00)$ & $(0.00)$ & $(0.41)$ \\
\hline & - & [3.03] & [1.65] & {$[-0.56]$} & [0.12] & [3.00] & {$[-3.03]$} & {$[-0.81]$} \\
\hline \multirow[t]{3}{*}{$\Delta \mathrm{GCF}$} & $13.696 * * *$ & & 1.273 & $3.785^{* *}$ & 0.081 & $-0.665 * * *$ & $0.440 * * *$ & -0.047 \\
\hline & $(0.00)$ & & $(0.26)$ & $(0.05)$ & (077) & $(0.00)$ & $(0.00)$ & $(0.38)$ \\
\hline & [6.13] & - & [1.28] & {$[-1.94]$} & [0.28] & {$[-6.36]$} & [6.13] & {$[-0.87]$} \\
\hline \multirow{3}{*}{$\Delta$ RRGT } & 0.254 & 0.116 & & 1.479 & 2.220 & $-0.180 * *$ & -0.114 & 0.082 \\
\hline & $(0.61)$ & $(0.73)$ & & $(0.22)$ & $(0.14)$ & $(0.02)$ & $(0.48)$ & $(0.45)$ \\
\hline & [0.50] & [0.26] & - & {$[-1.21]$} & {$[-1.49]$} & {$[-2.33]$} & [1.42] & {$[0.25]$} \\
\hline \multirow[t]{3}{*}{$\triangle \mathrm{RRPC}$} & $4.913^{* *}$ & $2.254^{*}$ & $3.922 * *$ & & $2.656^{*}$ & $-0.287 * *$ & -0.177 & 0.240 \\
\hline & $(0.03)$ & $(0.10)$ & $(0.05)$ & & $(0.10)$ & $(0.00)$ & (0.19) & $(0.23)$ \\
\hline & [2.21] & {$[-1.50]$} & [-1.98] & - & [1.62] & [-3.55] & {$[-1.30]$} & [1.21] \\
\hline \multirow[t]{3}{*}{$\Delta \mathrm{RRNL}$} & $5.925^{* * * *}$ & 0.983 & 0.423 & 2.028 & & $-0.490 * * *$ & 0.005 & 0.182 \\
\hline & $(0.00)$ & $(0.32)$ & $(0.51)$ & $(0.15)$ & & $(0.00)$ & $(0.97)$ & $(0.52)$ \\
\hline & [2.43] & {$[-0.99]$} & {$[-0.65]$} & {$[-1.42]$} & - & {$[-3.72]$} & [0.02] & [0.63] \\
\hline
\end{tabular}

Source: Calculated

Notes: Figures denote F-statistic values. p-values are in parentheses, t-statistics are in brackets. ECT indicates the estimated error-correction term.

* Indicate that the parameters are significant at the $10 \%$ level.

** Indicate that the parameters are significant at the 5\% level.

$* * *$ Indicate that the parameters are significant at the $1 \%$ level.

\section{CONCLUSIONS}

In this paper, we investigated the causal and cointegration relationships between transport infrastructure, investment in transport infrastructure and economic growth in Armenia, Georgia and Turkey over the period 1982-2010. For this purpose, unit root tests for panel, panel cointegration and causality techniques have been applied. Using panel unit root tests we found out that all variables are non-stationary and integrated of order one or I(1). For the robustness check, this paper used three kinds of panel cointegration tests, i.e. Pedroni’s (2004), Kao's (1999), and Johansen's Fisher panel cointegration tests. The tests proved the existence of more than one cointegrating vector indicating that the system under examination is stationary in more than one direction. The VECM results showed that gross capital formation and road/rail goods transported have a positive and statistically significant impact on economic growth in the short- run. On the other hand, the impact of road and rail passengers carried and road and rail network length variables are statistically insignificant in the shortrun. This highlights the importance of infrastructure investment and road/rail goods transported variable in the economic growth process in selected countries. Overall, the existence of bidirectional causality between economic growth and infrastructure investment, and between road and rail passengers carried and infrastructure investment was indicated in both the short and long-run.

Our results show that analyzed countries can gain a lot by investing in infrastructure and its performance. This means that to achieve higher economic development it requires institutional and organizational reforms, orientation on the quality of infrastructure instead of only quantitative goals.

Acknowledgments: Authors acknowledge financial support from their projects: APVV-0894-11 and VEGA1/0830/13. This work was co-funded by European
Community under project no 26220220180: Building Research Centre; AgroBioTech".

\section{REFERENCES}

ABADIR, K. M. - TAYLOR, A. M. 1999. On the Definitions of Co-integration. Journal of Time Series Analysis, 20(2). doi: http://dx.doi.org/10.1111/1467$\underline{9892.00128}$

ARMENIA'S TRANSPORT OUTLOOK. Transport Sector Master Plan. Asian Development Bank, 2011

ASCHAUER, D. A. 1988. Is public expenditure productive? Journal of Monetary Economics, 23(2), 177200.

BANISTER, D. - BERECHMAN, Y. 2001, Transport investment and the promotion of economic growth. Journal of Transport Geography, 9, 209e218.

doi: http://dx.doi.org/10.1016/0304-3932(89)90047-0

BREITUNG, J., 2000. The local power of some unit root tests for panel data. Adv. Econ. 15, 161-177.

doi: http://dx.doi.org/10.1016/S0731-9053(00)15006-6

CANNING, D. - PEDRONI, P. 1999. Infrastructure and Long Run Economic Growth. Discussion Paper No 57, Boston: Harvard Institute for International Development, Consulting Assistance on Economic Reform.

CANNING, D. - PEDRONI, P. 2004, The Effect of Infrastructure on Long Run Economic Growth. Williams College WP No. 2004-04

CENTER FOR GOVERNMENTAL STUDIES NORTHERN ILLINOIS UNIVERSITY DEKALB. April 2009. Role of Transportation in the Comprehensive Economic Development Strategy Planning Process: A Nationwide Scan

CHOI, I.. 2001. Unit root tests for panel data. Journal of International of Money and Finance, 20, 249-272.

doi: http://dx.doi.org/10.1016/S0261-5606(00)00048-6 COUNTRY INFRASTRUCTURE REPORT, Republic of Armenia, 2011 
COUNTRY REPORT IN INFRASTRUCTURE AND FINANCE, 2011, Georgia

DEMURGER, S. 2001. An Explanation for Regional Disparities in China? J. Comp. Econ., March 2001, 29(1), pp. 95-117.

DICKEY, D.A.- JANSEN, D.W.- THORNTON, D.L. 1994. A Primer on Cointegration with an Application to Money and Income. In: Rao, B.B. (Ed.). Cointegration for the Applied Economist. The Macmillan Press Ltd.

EGERT, B.- KOZLUK, T.- SUTHERLAND, D. 2009. Infrastructure and Growth: Empirical Evidence. William Davidson Institute WP No. 957.

ENGLE, R.F.- GRANGER, C.W.J. Cointegration and error correction: representation, estimation, and testing. Econometrica 1987; 55:251-76.

ESFAHANI, H. - RAMÍRES, M.T. 2003. Institutions, Infrastructure and Economic Growth. Journal of Development Economics 70, pp. 443-477.

doi: http://dx.doi.org/10.1016/S0304-3878(02)00105-0

FORD, R. - P. PORET 1991. Infrastructure and PrivateSector Productivity. OECD Economic Studies 17, pp. 63-89.

GRAMLICH, E. M. 1994. Infrastructure investment: a review essay. Journal of Economic Literature, 32, $1176 \mathrm{e} 1196$.

HADRI, K., 2000. Testing for stationarity in heterogeneous panel data. Econ. J. 3 (2), 148-161.

HERRANZ-LONCAN, A. 2007. Infrastructure investment and Spanish economic growth. 1850-1935. Explorations in Economic History, 44, 452-468.

doi: 10.1016/j.eeh.2006.06.002

HUANG, Q. - HARATA N. 2010. Role of Infrastructure in Economic Development. An Empirical Study for China Transportation Studies. 2010. pp. 166-173.

IM, K.S.- H.M. PESARAN - Y. SHIN 2003. Testing for Unit Roots in Heterogeneous Panels. Journal of Econometrics. 115(1), pp. 53-74. doi: http://dx.doi.org/10.1016/S0304-4076(03)00092-7

INLAND TRANSPORT SECURITY DISCUSSION FORUM, OSCE UNECE Roundtable, 12-13 December, Vienna, Austria

KAO, C., 1999. Spurious regression and residual-based tests for cointegration in panel data. Journal of Econometrics 90 (1), 1-44.

doi:http://www.sciencedirect.com/science/article/pii/S03 $\underline{04407698000232}$

INTERNATIONAL TRANSPORT FORM, OECD, 2013. Assessment of strategic plans and policy measures on investment and maintenance in transport infrastructure, Georgia.

INTERNATIONAL TRANSPORT FORM, OECD, 2009. Intermodal Transport, National Peer Review, Turkey

KAO, C.- CHIANG, M.H. - 2000. On the estimation and inference of a cointegrated regression in panel data. Advances in Econometrics. 15, 179-222.

doi: http://dx.doi.org/10.1016/S0731-9053(00)15007-8

KIRKPATRICK, C. - PARKER, D. - ZHANG, Y. 2004, Foreign Direct Investment in Infrastructure in Developing Countries: Does Regulation Make A
Difference? Centre on Regulation and Competition, WP No. 85, ISBN: 1-904056-84-9

KUMO, W. L. 2012, Infrastructure Investment and Economic Growth in South Africa: A Granger Causality Analysis. African Development Bank, Tunis, Tunisia, Working Paper Series No. 160

LEVIN, A., C. - LIN, F. - CHU, C.S.J. 2002. Unit Root Tests in Panel Data: Asymptotic and Finite-Sample Properties. Journal of Econometrics 108(1), pp. 1-24. doi: http://dx.doi.org/10.1016/S0304-4076(01)00098-7

MADDALA, G.S. - WU, S. 1999. A comparative study of unit root tests with panel data and a new simple test. Oxford Bulletin of Economics and Statistics, 61(Special Issue): 631-652. doi: http://dx.doi.org/10.1111/14680084.61.s1.13

MAESO-FERNANDEZ, F.- OSBAT, C.- SCHNATZ, B. 2006. Towards the estimation of equilibrium exchange rates for CEE acceding countries: methodological issues and a panel cointegration perspective. J. Comp. Econ. 34, 499-517. doi: 10.1016/j.jce.2006.05.003

MARK, N.C. - SUL, D. 2002. Cointegration vector estimation by panel DOLS and long-run money demand. NBER Technical Working Papers 0287, National Bureau of Economic Research, Inc. doi: http://dx.doi.org/10.1111/j.1468-0084.2003.00066.x

MUNNELL, A.H. 1990. How Does Public Infrastructure Affect Regional Economic Performance? New England Economic Review, Sept-Oct., 2-22.

PESARAN, H.M.- SHIN, Y.- SMITH R.P. Pooled mean group estimation of dynamic heterogeneous panels. $J$ Am Stat Ass. 1999;94:621-34. doi: http://dx.doi.org/10.2307/2670182

PEDRONI, P. 1999. Critical values for cointegration tests in heterogeneous panels with multiple regressors. Oxford Bulletin of Economics and Statistics, 61(Special Issue): 653-670.

doi: http://dx.doi.org/10.1111/1468-0084.61.s1.14

PEDRONI, P. 2000. Fully modified OLS for heterogeneous cointegrated panels. Advances in Economics, 15:93-130. doi: http://dx.doi.org/10.1016/S0731-9053(00)15004-2

PEDRONI, P., 2001. Purchasing power parity tests in cointegrated panels. Rev. Econ. Stat. 3 (A), 121 li. doi: http://dx.doi.org/10.1162/003465301753237803

PEDRONI, P. 2004. Panel cointegration: asymptotic and finite sample properties of pooled time series tests with an application to the PPP hypothesis. Econometric Theory, 20(3): 597-625

doi: http://dx.doi.org/10.1017/S0266466604203073

PHANG, S. 2003. Strategic development of airport and rail infrastructure: the case of Singapore. Transport Policy, 10, 27-33.

doi: http://dx.doi.org/10.1016/S0967-070X(02)00027-6

PRADHAN, R.P.- BAGCHI, T.P. 2013. Effect of Transportation Infrastructure on Economic Growth in India: The VECM Approach. Research in Transportation Economics, $38 \quad$ (2013) 139-148. doi: http://dx.doi.org/10.1016/j.retrec.2012.05.008

SHORT, J. - KOPP, A. 2005. Transport Infrastructure: investment and planning policy and research aspects. Transport Policy, 12, 360e367. 
doi: http://dx.doi.org/10.1016/j.tranpol.2005.04.003

TRANSPORTATION IN TURKEY. Country Report, Ministry of Transport and Communication, October 2011 WANG, E. C. 2002. Public infrastructure and economic growth: a new approach applied to East Asian Economies. Journal of Policy Modelling, 24, 411e435 doi: http://dx.doi.org/10.1016/S0161-8938(02)00123-0 WORLD BANK, WORLD DEVELOPMENT INDICATORS, 2012 [internet] available at www.worldbank.org (last visited 30. March, 2014)
UNITED NATIONS ECONOMIC COMMISSION FOR EUROPE, 2013 [internet] available at www.unece.org (last visited 30. March, 2014) 